\title{
Iron oxide nanoparticles effect on growth, physiological traits and nutritional contents of Moringa oleifera grown in saline environment
}

\author{
M. M. Tawfik', Magda H. Mohamed ${ }^{1}$, Mervat Sh. Sadak ${ }^{2,3^{*}}$ (10 and Alice T. Thalooth ${ }^{1}$
}

\begin{abstract}
Background: Using of nanoparticles in various aspects of life including agriculture, medicine and industry is very crucial. One of the important source for Fe nutrition in plants is Iron oxide nanoparticles $\left(\mathrm{Fe}_{3} \mathrm{O}_{4} \mathrm{NPs}\right)$ due to its efficiency in releasing under different $\mathrm{pH}$ range. Thus, in the Model Farm of National Research Centre Egypt at El Tour South Sinai, a field experiment was carried out, to study the effect of different concentration of $\mathrm{Fe}_{3} \mathrm{O}_{4} \mathrm{NPs}(0,20,40$, 60 ppm) on the physiological parameters and the nutritive value of Moringa under saline condition.

Results: The obtained results indicate that foliar spraying of $\mathrm{Fe}_{3} \mathrm{O}_{4} \mathrm{NPs}$ significantly promote growth (plant height, branches leaves number per plant, leaf area, stem diameter and biomass). Foliar treatment also increased photosynthetic pigments (chlo.a, chlo b, chlo a/b and carotenoids) and indole acetic acid (IAA) contents comparing with control. Hydrogen peroxide and lipid peroxidation contents of Moringa oleifera leaves were decreased significantly as compared with control plant. The maximum activities of antioxidant enzymes Peroxidase (POX), poly phenol oxidase (PPO), super oxide dismutase (SOD) and nitrate reductase (NR) were observed in plants treated with $40 \mathrm{ppm}$. Different concentrations of $\mathrm{Fe}_{3} \mathrm{O}_{4} \mathrm{NPs}$ increased significantly crude protein, crude fiber and ash percentages as well as, some nutrient contents of moringa leaves ( $\mathrm{N}, \mathrm{P}, \mathrm{K}$ and $\mathrm{K} / \mathrm{Na}$ ) compared with untreated control plants, meanwhile decreased Na contents.
\end{abstract}

Conclusion: Treatment of Moringa oleifera plant with $\mathrm{Fe}_{3} \mathrm{O}_{4} \mathrm{NPs}$ at different concentrations greatly decrease the harmful effect of salinity on growth by its promotive role on different studied biochemical and physiological aspects.

Keywords: $\mathrm{Fe}_{3} \mathrm{O}_{4} \mathrm{NPs}$, Growth, Moringa oleifera, Physiological parameters, Saline environment

\section{Background}

Moringaa oleifera is referred to "miracle vegetable". It belongs to the Moringaceae family. It is a perennial herb and it is a common ingredient in functional foods and pharmaceuticals. It is used as a nutritional additive because of its high contents of essential amino acid, some vitamins such as vitamin $A, B, C$ and $E$, various minerals, some bioactive secondary metabolites such flavonoids,

\footnotetext{
*Correspondence: mervat_sh24@yahoo.com

${ }^{3} 33$ El Bohouth st, P.O. 12622, Giza, Egypt

Full list of author information is available at the end of the article
}

glucoinolate and phenolics (Anwar et al. 2007; Ezzo et al. 2018). Furthermore, Moringa oleifera seeds are regarded as oil plant because they have $62-75 \%$ oleic acid of $80 \%$ unsaturated fatty acids. It is also a powerful antioxidant thus; it is used in food products, cosmetics and lubricants (Zheng et al. 2017). Moringa oleifera can be used in water purification (Eman 2014; Mekonnen 2016).

Salinity remains the biggest negative environmental challenge, because elevated levels of sodium chloride are commonly found in many farm zones. Hence, the great restriction facing agriculture in arid and semiarid zones due to increased salt levels both in soil and irrigation water, which hinder growth and productivity of various crops. One of the main causes of salt over accumulation 
in soil is irrigation with poor water. Salinity stress cause both osmotic and ionic stresses on plant cells. Osmotic stress due to the excessive level of salt in soil, which hampered plant's ability to absorb and retain water (Omisun et al. 2018). Ionic stress even, is produced by an ionic imbalance, which alters the proportion of potassium $\left(\mathrm{K}^{+}\right)$to sodium $\left(\mathrm{Na}^{+}\right)$. The rise in of $\mathrm{Na}^{+}$can affect chlorophyll formation either by suppressing the biosynthesis of chlorophyll or speeding up its destruction, causing a decline in the rate of photosynthesis (Karimi et al. 2011). Furthermore, reactive oxygen species (ROS) contents also increased by increased $\mathrm{Na}^{+}$content, causing harmful effect, such as protein destruction, DNA mutation, and lipid peroxidation (Munns et al. 2006; Farhangi-Abriz and Ghassemi-Golezani 2018).

Both soil salinity and global water scarcity cause reduction in agricultural productivity. Salinity in the soil reduces the availability and competitive absorption of nutrients and in turn affect on crop (Silva et al. 2008). To sustain soil and turgor water absorption, the plant's internal water capacity must be lower than of the soil. This impact is induced by an increase in osmotic pressure caused by soil solute uptake. This involves an increase in osmotic, either by soil solutes absorption or synthesis of suitable solutes (Tester and Davenport 2003). Increased levels of these solutes resulted in more water taking up from the soil and a decline in water level in plant cell (Nanjo et al. 1999). Survival of plants under such stress environment depends on the ability of plants to perceive the stimulus, generate and transmits signals and instigates physiological alterations thus maintain metabolic processes accordingly (Dolatabadian and Saleh 2009). Adipate with salinity is the only way to provide alimentary agriculture production in saline setting (Al-Rawahy et al. 2011). Therefore, an appropriate arrangement to minimize the harmful effects of salinity must be found (Alharby et al. 2016).

Nanotechnology a rapidly developing field recently, has had an important role on people's life and has improved quality of life through a variety of fields (Tripathi et al. 2017). Nanoparticles have essential characters such as increase surface-to-volume ratio, thermal, optical and electrical characters, in addition to physical, chemical and biological characters in terms of absorption and activity (Rastogi et al. 2017). It is a procedure for producing, manipulating and deploying nanomaterials into a device (Baruah and Dutta 2009). This technique enables nanoparticles (NPs) with at least one dimension in the order of $100 \mathrm{~nm}$ or less (Auffan et al. 2009). Therefore, nanomaterials hold great promise regarding their application in agriculture in terms of plant nutrition and protection (Cossins 2014) due to their size-dependent qualities, high surface-to-volume ratio, and unique optical properties
(Dimetry and Hany, 2016). It also modifies material at the nuclear, atomic, atomic or macromolecular level to create nanoscale objects with novel properties due to their small size.

Iron $(\mathrm{Fe})$ is an important microelement affected on different physiological and biochemical processes and ranks the fourth abundant elements regarding to its value, however its quantity is poor or inadequate for plant needing (Askary et al. 2016, 2017). Iron is essential to normal plant growth, development and play important roles in enzyme reactions, photosynthesis, improves the performance of photosystems, DNA transcription, RNA synthesis and auxin activity (Sheykhbaglou et al. 2018). Since $\mathrm{Fe}$ is often present in the insoluble $\mathrm{Fe}^{3+}$ form, particularly in increased $\mathrm{pH}$ and aerobic soil, such soils are iron-deficient (Rui et al. 2016). Using of nanoparticles to treat iron deficiency is one alternative due to poor solubility of minerals containing iron, as well as, improve plant tolerance to different abiotic stress (Askary et al. 2017). Iron nanoparticles reacts at a molecular level inside plant cells have the ability to improve nutrient uptake (Hasan et al. 2011). Several reports about remedy the harmfully effects of salinity by magnetic iron on the other plants are available, El-Sayed (2014) postulated that magnetic water enhanced growth, yield and water content of broad bean plants grown in saline soil. Moreover, chlorophyll a, chlorophyll b, carotenoids, total carbohydrates, protein, total amino acids, proline, total indoles, phenols, $\mathrm{P}, \mathrm{K}, \mathrm{Na}$ and $\mathrm{Ca}$ contents were also improved in all parts of plant under salt stress by treatment with magnetic iron. Shahrekizada et al. (2015) investigated the effect of Nano- $\mathrm{Fe}_{3} \mathrm{O}_{4}$-EDTA fertilizer on aerial organ biomass, number of leaves, plant height, chlorophyll content as well as elemental quantities of sunflower plants and observed stimulatory effects of Nano- $\mathrm{Fe}_{3} \mathrm{O}_{4}$-EDTA fertilizer.

Magnetite nanoparticles (MNPs) have some advantages in biocompatibility, biodegradability (Yew et al. 2016) and easily encapsulated. It has been indicated also that MNPs has characterized physiochemical and super paramagnetism that affect biomass and biochemical properties and in turn plant (Abou El-Nasr et al. 2015).

Therefore, the aim of this research is to study the effect of magnetite nanoparticles (MNPs) treatments on growth, photosynthetic pigments content, some physiological aspects as well as crude content of Moringa oleifera L.

\section{Methods}

A field experiment was conducted in the Model Farm of National Research centre, El Tour, South Sinai to study the impact of $\mathrm{Fe}_{3} \mathrm{O}_{4}$ nanoparticles on growth and some phsiochemical parameter of Moringa. Plants were transplanted in El Tour, South Sinai at 18th Sep 2019 
Table 1 Water analysis of Abo Kalam well, El Tour. South Sina

\begin{tabular}{ll}
\hline $\mathrm{pH}$ & 7.49 \\
$\mathrm{EC} \mathrm{dS}^{-1}$ & 8.7 \\
Soluble cations (Meq/L) & \\
$\mathrm{K}^{+}$ & 0.5 \\
$\mathrm{Na}^{+}$ & 69.2 \\
$\mathrm{Mg}^{++}$ & 11.9 \\
$\mathrm{Ca}^{++}$ & 21.6 \\
$\mathrm{Soluble}^{+}$anions (Meq/L) & \\
$\mathrm{SO}_{4}^{-}$ & 26.6 \\
$\mathrm{Cl}^{-}$ & 74.2 \\
$\mathrm{HCO}_{3}^{-}$ & 2.4 \\
$\mathrm{CO}^{-}$ & - \\
\hline
\end{tabular}

Table 2 Chemical and mechanical analysis of the soil

\begin{tabular}{lll}
\hline Depth & $00-30 \mathrm{~cm}$ & $30-60 \mathrm{~cm}$ \\
Soil texture & Sandy soil & Sandy soil \\
$\mathrm{pH}$ & 8.1 & 8.4 \\
$\mathrm{EC} \mathrm{dS}$ & 15.1 & 4.52 \\
Soluble cations (Meq/L) & & \\
$\mathrm{K}^{+}$ & 0.4 & 0.24 \\
$\mathrm{Na}^{+}$ & 112.0 & 27.0 \\
$\mathrm{Mg}^{++}$ & 28.8 & 5.5 \\
$\mathrm{Ca}^{++}$ & 60.5 & 12.5 \\
$\mathrm{Soluble}^{+}$anions (Meq/L) & & \\
$\mathrm{SO}^{-}$ & 61.0 & 10.64 \\
$\mathrm{Cl}^{-}$ & 139.0 & 31.0 \\
$\mathrm{HCO}_{3}^{-}$ & 2.7 & 3.6 \\
$\mathrm{CO}^{-}$ & - & - \\
\hline
\end{tabular}

grown under drip irrigation system with saline water $\left(\mathrm{EC} 8.7 \mathrm{dSm}^{-1}\right.$ ), water analysis of Abo Kalam Well are presented in Table 1.

Experiment was laid out in completely randomized block $(0.5 \times 1.5 \mathrm{~m}$ distance between plants $)$ i.e. 5600 plants /fed., the mechanical and chemical analysis of the soil was carried out by using the standard method described by Klute (1986) Table 2. Each plant was fertilized with $20 \mathrm{~g}$ calcium superphosphate $\left(15.5 \% \mathrm{P}_{2} \mathrm{O}_{5}\right)$ and $10 \mathrm{~g}$ potassium sulphate $\left(48.0 \% \mathrm{~K}_{2} \mathrm{O}\right)$ and $20 \mathrm{~g}$ urea $(46.5 \% \mathrm{~N})$ mixed with 300 g green manures. Foliar spraying with $\mathrm{Fe}_{3} \mathrm{O}_{4}$ nanoparticles (control, 20, 40 and $60 \mathrm{ppm}$ ) was applied 45 days from transplantation and 30 days later.

After 210 days from transplantation four replicates of representative samples from each treatment was taken to record plant height $(\mathrm{cm})$, stem diameter $(\mathrm{cm})$, number of branches and leaves per plant, leaf area $\left(\mathrm{cm}^{2}\right)$ and total biomass (dry wt.gm/plant).
Measurements: Photosynthetic pigments content were determined as $\mathrm{mg} / \mathrm{gm}$ fresh weight (chlorophyll a, chlorophyll b, carotenoids and total pigments according to Lichtenthaler and Buschmann (2001). Indole acetic acid (IAA) content was extracted and analysed by the method of Gusmiaty et al. (2019). Proline and free amino acid content were extracted according to the method described by Vartainan et al. (1992). Proline was estimated according to Bates et al. (1973). Free amino acid was determined with the ninhydrin reagent method (Yemm and Cocking 1955). The procedure for the extraction of TSS from stem, leaf, and pod wall was described by Ciha and Brun (1978). TSS was quantified using a modified phenolsulfuric acid assay (Zhang 1993). The hydrogen peroxide $\left(\mathrm{H}_{2} \mathrm{O}_{2}\right)$ level was colorimetrically measured as described by Jana and Choudhuri (1981). Lipid peroxidation was determined by estimating the malondialdehyde content following the method of Heath and Packer (1968). For enzyme determination: The method used for extracting the enzyme was that of (Mukherjee and Choudhuri 1983). Peroxidase (POX, EC 1.11.1.7) activity assayed according to the method described by Bergmeyer (1974). Polyphenol oxidase (PPO, EC 1.10.3.1) activity assayed using the method of Kar and Mishra (1976). Superoxide dismutase (SOD, EC 1.12.1.1) activity measured according to the method of Dhindsa et al. (1981). The activity of nitrate reductase (NR, EC 1.7.1.1) was measured according to Jaworski (1971). The contents of sodium and potassium were determined in the digested material using Jenway flame photometer as described by Eppendrof and Hing( 1970). $\mathrm{K} / \mathrm{Na}$ ratio was also calculated for each treatment. Crude protein was calculated by multiplying nitrogen contents by 5.75 . Crude fiber and ash were determined by standard analytical methods after (AOAC 2010). Nitrogen was determined with micro Kjeldhal's apparatus according to the method described by AOAC (2010). Crude protein was calculated by multiplying nitrogen contents by 5.75. Analysis of variance (ANOVA) for completely randomized block and LSD at 5\% to compare mean were used by M-STAT-C statistical analysis program (MSTAT 1988).

\section{Results}

Effect of $\mathrm{Fe}_{3} \mathrm{O}_{4}$ nanoparticles on some growth parameter and total biomass of Moringa oleifera $\mathrm{L}$.

The obtained results as presented in Table 3 show that, plant height $(\mathrm{cm}$.) increased gradually and significantly with increasing concentration of $\mathrm{Fe}_{3} \mathrm{O}_{4}$ NPs. The highest increase in plant height obtained with 60 ppm $\mathrm{Fe}_{3} \mathrm{O}_{4}$ NPs, while the least plant height recorded in control plant $\left(0 \mathrm{Fe}_{3} \mathrm{O}_{4}\right)$. The same table also showed that, the highest number of branches and leaves/plant were recorded 
Table 3 Effect of $\mathrm{Fe}_{3} \mathrm{O}_{4}$ nanoparticles treatments on some growth parameter of Moringa oleifera $\mathrm{L}$.

\begin{tabular}{lllllll}
\hline $\mathrm{Fe}_{\mathbf{3}} \mathbf{O}_{\mathbf{4}} \mathbf{N P s}(\mathbf{p p m})$ & $\begin{array}{l}\text { Length of the } \\
\text { plant }(\mathbf{c m})\end{array}$ & $\begin{array}{l}\text { No. of branch/ } \\
\text { plant }\end{array}$ & $\begin{array}{l}\text { No. of leaves/ } \\
\text { plant }\end{array}$ & Leaf area $\left(\mathbf{c m}^{2}\right)$ & $\begin{array}{l}\text { Stem diameter } \\
(\mathbf{c m})\end{array}$ & $\begin{array}{l}\text { Total biomass } \mathbf{( g} \\
\mathbf{d r y} \text { wt / } \mathbf{p l a n t})\end{array}$ \\
\hline 0 & 84.49 & 22.60 & 26.78 & 35.23 & 1.91 & 58.37 \\
20 & 88.44 & 23.10 & 27.88 & 36.69 & 2.17 & 66.52 \\
40 & 91.10 & 23.14 & 32.23 & 39.60 & 2.32 & 74.38 \\
60 & 92.28 & 22.21 & 28.62 & 37.66 & 2.07 & 68.47 \\
LSD 5\% & 7.28 & NS & NS & 3.98 & 0.14 & 4.30 \\
\hline
\end{tabular}

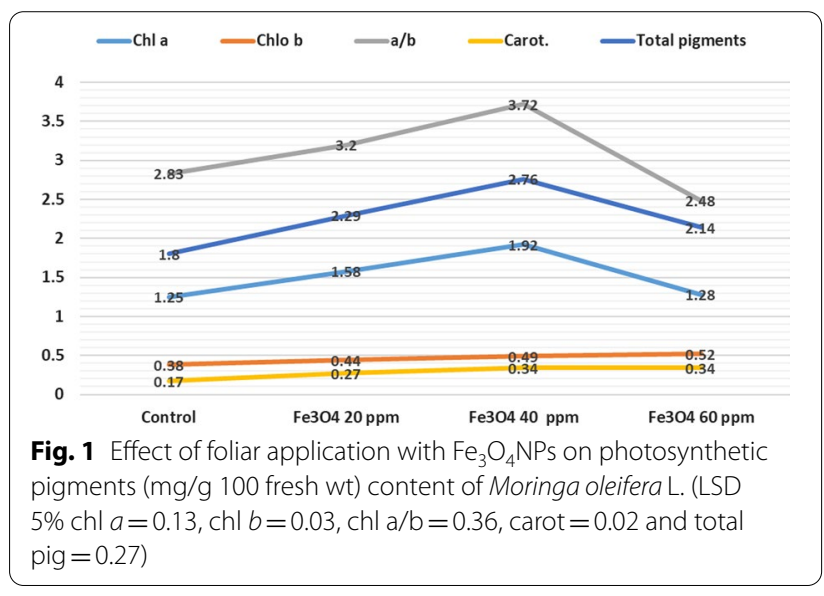

with 40 ppm of $\mathrm{Fe}_{3} \mathrm{O}_{4}$ NPs without significant differences between other treatments.

Moreover, foliar application of $\mathrm{Fe}_{3} \mathrm{O}_{4}$ NPs significantly increased leaf area $\left(\mathrm{cm}^{2}\right)$, stem diameter $(\mathrm{cm})$ and total biomass (g) dry wt/plant. Furthermore, the highest increases of leaf area $\left(39.60 \mathrm{~cm}^{2}\right)$, stem diameter $(2.32 \mathrm{~cm})$ and total biomass $(74.38 \mathrm{~g})$ dry wt/plant were recorded in plants sprayed with $40 \mathrm{ppm} \mathrm{Fe}_{3} \mathrm{O}_{4} \mathrm{NPs}$. However, increasing concentration of $\mathrm{Fe}_{3} \mathrm{O}_{4} \mathrm{NPs}$ up to $60 \mathrm{ppm}$ caused progressive reduction in these growth parameters compared with $\mathrm{Fe}_{3} \mathrm{O}_{4}$ NPs at $40 \mathrm{ppm}$ except plant height. Foliar application with $\mathrm{Fe}_{3} \mathrm{O}_{4} \mathrm{NPs}$ of moringa plants gave superiority in inducing the highest degree of adaptation under saline habitat, which resulted in significant increases in most studied growth parameters and dry matter accumulation.

\section{Effect of foliar application with $\mathrm{Fe}_{3} \mathrm{O}_{4} \mathrm{NPs}$}

on photosynthetic pigments content of Moringa oleifera $\mathrm{L}$. As indicated in Fig. 1 it is clearly show that different concentrations of $\mathrm{Fe}_{3} \mathrm{O}_{4} \mathrm{NPs}$, significantly increased photosynthetic pigments as compared with untreated control. It is evident that foliar application with $\mathrm{Fe}_{3} \mathrm{O}_{4} \mathrm{NPs}$ at $40 \mathrm{ppm}$ has the most advantageous effect on photosynthetic pigments content as compared to other treatments.

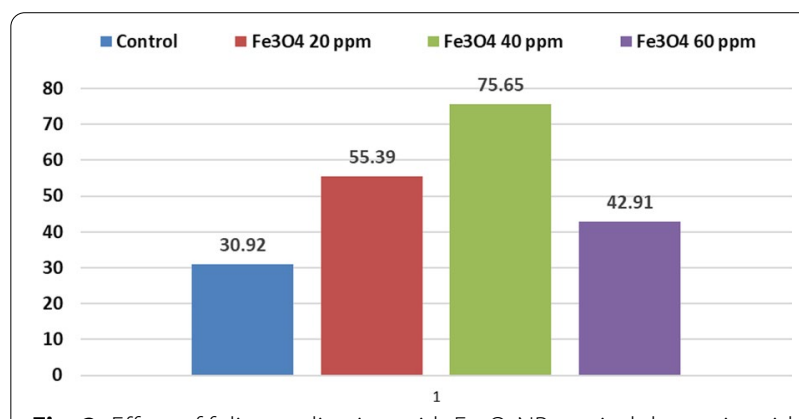

Fig. 2 Effect of foliar application with $\mathrm{Fe}_{3} \mathrm{O}_{4} \mathrm{NPs}$ on indole acetic acid content ( $\mu \mathrm{g} / \mathrm{g}$ fresh Wt) of Moringa oleifera L (LSD 5\%=5.33)

Effect of foliar application with $\mathrm{Fe}_{3} \mathrm{O}_{4} \mathrm{NPs}$ on indole acetic acid content of Moringa oleifera $\mathrm{L}$.

The effect of foliar treatment of different concentrations of $\mathrm{Fe}_{3} \mathrm{O}_{4} \mathrm{NPs}$ on indole acetic acid (IAA) contents of Moringa oleifera L. grown under saline condition is presented in Figure 2. Foliar treatment with different concentrations of $\mathrm{Fe}_{3} \mathrm{O}_{4}$ nanoparticles induced significant increases in IAA content of Moringa oleifera L. as compared with untreated control plant. It is clear that, increasing concentration of $\mathrm{Fe}_{3} \mathrm{O}_{4}$ nanoparticles significantly increased IAA content up to $\mathrm{Fe}_{3} \mathrm{O}_{4} 40 \mathrm{ppm}$ which caused the highest increase in IAA content as compared with other treatments, then treatment with $60 \mathrm{ppm}$ decreased IAA content but still greater than control plants.

\section{Effect of foliar application with $\mathrm{Fe}_{3} \mathrm{O}_{4} \mathrm{NPs}$ on osmoprotectants (proline, free amino acids and total soluble sugars) of Moringa oleifera $\mathrm{L}$.}

The obtained data presented in Table 4 show that, different concentrations of $\mathrm{Fe}_{3} \mathrm{O}_{4}$ nanoparticles foliar treatment caused significant increases in the content of proline, free amino acids and total soluble sugars of Moringa oleifera L. plant grown under saline conditions as compared with controls. The data also show that the largest record of the studied osmolyte resulted by the foliar application of $40 \mathrm{ppm} \mathrm{Fe}_{3} \mathrm{O}_{4} \mathrm{NPs}$ treatment. 
Table 4 Effect of foliar application with $\mathrm{Fe}_{3} \mathrm{O}_{4} \mathrm{NPS}$ on osmoprotectants (proline, free amino acids and total soluble sugars) of Moringa oleifera $\mathrm{L}$.

\begin{tabular}{lccr}
\hline $\mathrm{Fe}_{\mathbf{3}} \mathbf{O}_{\mathbf{4}}$ NPs $(\mathbf{p p m})$ & Proline & Free amino acids & \multicolumn{1}{c}{ TSS } \\
\hline 0 & 24.52 & 349.41 & 89.55 \\
20 & 32.88 & 468.54 & 124.74 \\
40 & 37.01 & 527.39 & 142.13 \\
60 & 31.79 & 452.94 & 120.13 \\
$\mathrm{LSD} 5 \%$ & 1.68 & 21.03 & 7.56 \\
\hline
\end{tabular}

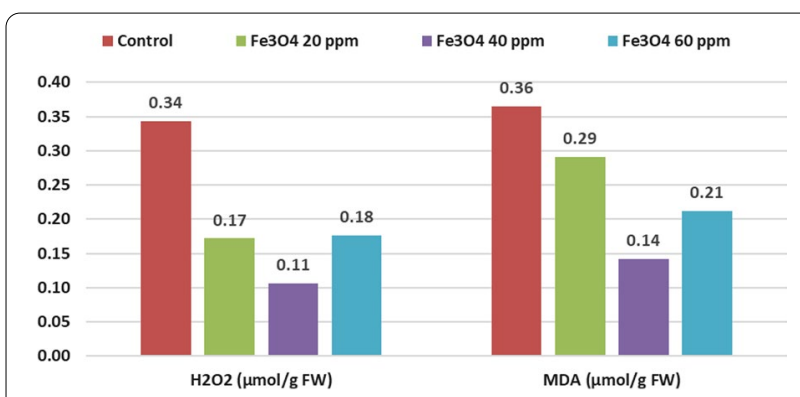

Fig. 3 Effect of foliar application with $\mathrm{Fe}_{3} \mathrm{O}_{4} \mathrm{NPs}$ on hydrogen perxide and lipid peroxidation of Moringa oleifera L. (LSD 5\%: $\mathrm{H}_{2} \mathrm{O}_{2}=0.012$ \& $\mathrm{MDA}=0.008$

Effect of foliar application with $\mathrm{Fe}_{3} \mathrm{O}_{4} \mathrm{NPs}$ on hydrogen perxide and lipid peroxidation of Moringa oleifera $\mathrm{L}$.

The effect of foliar treatment with different concentrations of $\mathrm{Fe}_{3} \mathrm{O}_{4}$ NPs on $\mathrm{H}_{2} \mathrm{O}_{2}$ and MDA contents of Moringa oleifera L. plant grown under saline condition are presented in (Fig. 3). Data revealed that the contents of $\mathrm{H}_{2} \mathrm{O}_{2}$ and MDA were decreased with increasing $\mathrm{Fe}_{3} \mathrm{O}_{4}$ NPs levels up to $40 \mathrm{Fe}_{3} \mathrm{O}_{4}$ NPs then increased with 60 ppm treatment but still lower than control plant as compared with untreated control plant.

\section{Effect of foliar application with $\mathrm{Fe}_{3} \mathrm{O}_{4}$ NPs on Antioxidant enzymes (POX, PPO, SOD and NR) of Moringa oleifera L.}

Data presented in Table 5 show that, foliar treatment of $\mathrm{Fe}_{3} \mathrm{O}_{4}$ NPs caused significant increases in antioxidant enzymes Peroxidase (POX), poly phenol oxidase (PPO), super oxide dismutase (SOD) and nitrate reductase (NR)) of Moringa oleifera L. leaves as compared with untreated plants (control). Maximum increases were obtained by treatment of Moringa oleifera L. plants with 40 ppm of $\mathrm{Fe}_{3} \mathrm{O}_{4}$ nanoparticles (Table 5).

\section{Effect of foliar application with $\mathrm{Fe}_{3} \mathrm{O}_{4} \mathrm{NPs}$ on nutritional values of Moringa oleifera $\mathrm{L}$.}

Data in Fig. 4 shows the effect of different concentrations of foliar application of treatments on nutritional values of Moringa oleifera L. Foliar application
Table 5 Effect of foliar application with $\mathrm{Fe}_{3} \mathrm{O}_{4} \mathrm{NPs}$ on antioxidant enzymes POX, PPO, SOD (U/min/g FW) and $\mathrm{NR}\left(\mathrm{nM} \mathrm{NO}_{2} / \mathrm{g} \mathrm{FW/h}\right)$ of Moringa oleifera $\mathrm{L}$.

\begin{tabular}{llrrr}
\hline $\mathrm{Fe}_{\mathbf{3}} \mathbf{O}_{\mathbf{4}} \mathbf{N P s}(\mathbf{p p m})$ & POX & PPO & \multicolumn{1}{l}{ SOD } & \multicolumn{1}{l}{ NR } \\
\hline 0 & 373.758 & 23.793 & 24.524 & 394.278 \\
20 & 501.189 & 32.153 & 32.884 & 521.709 \\
40 & 564.143 & 36.283 & 37.014 & 584.663 \\
60 & 484.498 & 31.058 & 31.789 & 505.018 \\
$\mathrm{LSD} 5 \%$ & 28.235 & 2.015 & 2.018 & 29.321 \\
\hline
\end{tabular}

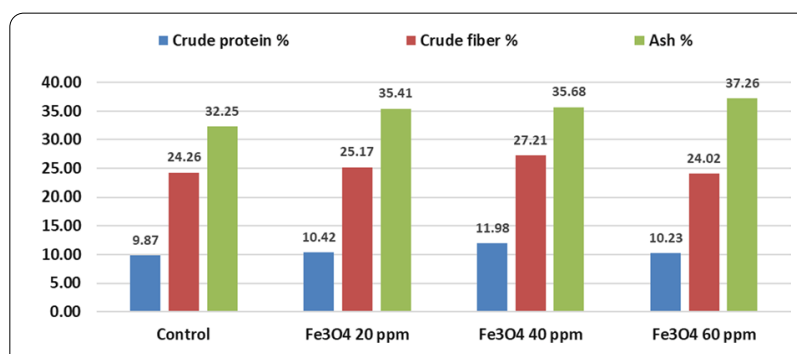

Fig. 4 Effect of foliar application with $\mathrm{Fe}_{3} \mathrm{O}_{4} \mathrm{NPs}$ on nutritional values of Moringa oleifera L (LSD 5\%: crude protein $=0.56$ \& crude fiber $=1.21 \&$ Ash $=1.87$ )

Fig. 5 Effect of foliar application with $\mathrm{Fe}_{3} \mathrm{O}_{4} \mathrm{NPs}$ on nutrients content of Moringa oleifera L. (LSD 5\%: $\mathrm{N} \%=0.09, \mathrm{P} \%=0.06, \mathrm{~K} \%=0.10, \mathrm{Na}$ $\%=N S, K / N a=K / N a)$

with $\mathrm{Fe}_{3} \mathrm{O}_{4} \mathrm{NPs}$ different concentrations $(0,20,40$ and $60 \mathrm{ppm}$ ) caused significant increases in nutritional values in comparison to control plants. It is clear from Fig. 4 that, foliar application with $40 \mathrm{ppm} \mathrm{Fe}_{3} \mathrm{O}_{4} \mathrm{NPs}$ recorded the highest values for the content of crude protein, crude fiber and ash in plant leaves.

\section{Effect of foliar application with $\mathrm{Fe}_{3} \mathrm{O}_{4} \mathrm{NPs}$ on nutrients content of Moringa oleifera $\mathrm{L}$.}

Data in Fig. 5 showed that, foliar application with $\mathrm{Fe}_{3} \mathrm{O}_{4}$ NPs different concentrations, significantly and 
gradually increased contents of $\mathrm{N}, \mathrm{P}, \mathrm{K}, \mathrm{Na}$ and $\mathrm{K} / \mathrm{Na}$ values as compared with control treatment. However, plants sprayed with $40 \mathrm{ppm} \mathrm{Fe}_{3} \mathrm{O}_{4}$ recorded the highest values of $\mathrm{N}, \mathrm{P}$ and $\mathrm{K}$ as well as $\mathrm{K} / \mathrm{Na}$. On the contrary, the lowest $\mathrm{Na}$ content was recorded under same treatment. The increase of $\mathrm{N}, \mathrm{P}$ and $\mathrm{K}$ in this experiment could be due to the promotional effect of $\mathrm{Fe}_{3} \mathrm{O}_{4}$ NPs on growth, physiological and biochemical processes of Moringa oleifera $\mathrm{L}$.

\section{Discussion}

\section{Effect of $\mathrm{Fe}_{3} \mathrm{O}_{4}$ nanoparticles on some growth parameter} and total biomass of Moringa oleifera $\mathrm{L}$.

Foliar application with $\mathrm{Fe}_{3} \mathrm{O}_{4} \mathrm{NPs}$ of moringa plants gave superiority in inducing the highest degree of adaptation under saline habitat, which resulted in significant increases in most studied growth parameters and dry matter accumulation. These results confirmed by the finding of Abdel-Fattah (2014) he declared that application of magnetite, 3 times at the rate of $4 \mathrm{~g} /$ pot improved vegetative growth of Jacaranda acutifolia seedlings grown in salinized soil up to $4000 \mathrm{ppm}$. Also, Shankramma et al. (2016) stated that magnetic iron (III) oxide nanoparticles $\left(\mathrm{Fe}_{3} \mathrm{O}_{4} \mathrm{NPs}\right)$ increased growth parameters of tomato plant. In addition, Sanati et al. (2018) confirmed our results on Capsicum annuum plant. This enhanced role of magnetic iron (III) oxide nanoparticles $\left(\mathrm{Fe}_{3} \mathrm{O}_{4} \mathrm{NPs}\right)$ might be ascribed to the role of magnetic iron in enhancing of $\mathrm{N}, \mathrm{P}$ and $\mathrm{K}$ uptake which stimulate plant growth rather than the harmful effect of $\mathrm{Na}$ and $\mathrm{Cl}$ which inhibit plant growth (Sodium and chloride ions separate when salts are dissolved in water. The dissolved sodium and chloride ions, in high concentrations, can displace other mineral nutrients in the soil. Plants then absorb chlorine and sodium instead of needed plant nutrients such as potassium and phosphorus, leading to deficiencies). It induces cell metabolism and mitosis of meristematic cells (Askary et al. 2017).

\section{Effect of foliar application with $\mathrm{Fe}_{3} \mathrm{O}_{4} \mathrm{NPs}$} on photosynthetic pigments content of Moringa oleifera $\mathrm{L}$. The effect of foliar spraying with $\mathrm{Fe}_{3} \mathrm{O}_{4} \mathrm{NPs}$ on photosynthetic pigments of moringa plants is shown in Fig. 1. Data clearly indicated that, different treatments of $\mathrm{Fe}_{3} \mathrm{O}_{4} \mathrm{NPs}$, significantly increased photosynthetic pigments constituents (Chl a, Chl b, carotenoids and total pigments) as compared with untreated control plants. Our results were concurrent with those of Siddiqui et al. (2015), Bastani et al. (2018), Sheykhbaglou et al. (2018) on different plant species. Moreover, Ahmed et al. (2016) concluded that the leaf content of chlorophyll a, b and carotenoids was gradually decreased with increasing salinity level, but was progressively increased as the rate of $\mathrm{Fe}_{3} \mathrm{O}_{4}$ was increased. The enhancing effect of nano $\mathrm{Fe}_{3} \mathrm{O}_{4}$ treatment could be attributed to the role of iron in the synthesis of protochlorophyllide from magnesium protoporfyrin complex. It is also participate in the synthsis of aminoleyulinic acid and as coenzyme (Mengel 1991). Furthermore, iron is important in plant growth and development for a wide range of biochemical processes from photosynthesis to respiration. Fe is essential for maintaining the chloroplast structure and function, for biosynthesis of $\mathrm{Fe}-\mathrm{S}$ clusters and chlorophyll (Chl), and is involved in the electron transport systems (Broadley et al. 2012; Briat et al. 2015; Mai and Bauer 2016).

\section{Effect of foliar application with $\mathrm{Fe}_{3} \mathrm{O}_{4} \mathrm{NPs}$ on indole acetic acid content of Moringa oleifera $\mathrm{L}$.}

The effect of foliar treatment of different concentrations of $\mathrm{Fe}_{3} \mathrm{O}_{4} \mathrm{NPs}$ on indole acetic acid (IAA) contents of Moringa oleifera $\mathrm{L}$. grown under saline condition is presented in (Fig. 2). Foliar treatment with different concentrations of $\mathrm{Fe}_{3} \mathrm{O}_{4}$ nanoparticles induced significant increases in IAA content of Moringa oleifera L. as compared with untreated control plant. Similar results were obtained by El-Sayed (2014) who confirmed the positive role of magnetic water on increasing total indole content of broad bean plants grown under saline soil. The increased levels of endogenous IAA contents of Moringa olefera L plant in response to $\mathrm{Fe}_{3} \mathrm{O}_{4} \mathrm{NPs}$ might be due to its promotive role in IAA biosynthesis via activiation of enzymes and/ or decreasing IAA degradation.

\section{Effect of foliar application with $\mathrm{Fe}_{3} \mathrm{O}_{4} \mathrm{NPs}$ on osmoprotectants (proline, free amino acids and total soluble sugars) of Moringa oleifera $\mathrm{L}$.}

The obtained data presented in Table 4 show that, different concentrations of $\mathrm{Fe}_{3} \mathrm{O}_{4}$ nanoparticles foliar treatment under saline condition caused significant increases in the content of proline, free amino acids and total soluble sugars of Moringa oleifera L. plants conditions as compared with controls. Our result are supported by the findings of Soliman et al. (2015) they stated that, $\mathrm{ZnO}$ and $\mathrm{Fe}_{3} \mathrm{O}_{4}$ nanoparticles induced proline synthesis, and improved tolerance to abiotic stress. Proline, free amino acids and total soluble sugars contents of plant cells play an important role in osmotic adjustment under stress thus protecting macromolecules structure and membranes of cell. Moreover, stabilization of components of sub cellular and free radical and cellular redox buffering induced by proline (Kaur and Asthir 2015) (Table 6). 
Table 6 Effect of foliar application with $\mathrm{Fe}_{3} \mathrm{O}_{4} \mathrm{NPs}$ on proline, free amino acids and total soluble sugars ( $\mathrm{mg} / 100 \mathrm{~g}$ dry $\mathrm{wt}$ ) of Moringa oleifera $\mathrm{L}$

\begin{tabular}{lccr}
\hline $\mathrm{Fe}_{\mathbf{3}} \mathbf{O}_{\mathbf{4}}$ NPs $(\mathbf{p p m})$ & Proline & Free amino acids & \multicolumn{1}{c}{ TSS } \\
\hline 0 & 24.52 & 349.41 & 89.55 \\
20 & 32.88 & 468.54 & 124.74 \\
40 & 37.01 & 527.39 & 142.13 \\
60 & 31.79 & 452.94 & 120.13 \\
$\mathrm{LSD} \mathrm{5} \%$ & 1.68 & 21.03 & 7.56 \\
\hline
\end{tabular}

Effect of foliar application with $\mathrm{Fe}_{3} \mathrm{O}_{4} \mathrm{NPs}$ on hydrogen perxide and lipid peroxidation of Moringa oleifera $\mathrm{L}$.

The effect of foliar treatment with different concentrations of $\mathrm{Fe}_{3} \mathrm{O}_{4}$ NPs on $\mathrm{H}_{2} \mathrm{O}_{2}$ and MDA contents of Moringa oleifera L. plant grown under saline condition are presented in Figure 3. Data revealed that the contents of $\mathrm{H}_{2} \mathrm{O}_{2}$ and MDA were decreased with increasing $\mathrm{Fe}_{3} \mathrm{O}_{4}$ NPs levels up to $40 \mathrm{Fe}_{3} \mathrm{O}_{4}$ NPs then increased with 60 ppm treatment but still lower than control plant as compared with untreated control plant. Malonyldialdehyde (MDA) is known as marker to assume the degree of peroxidation of lipids and injure of plasmalemma and membranes of organelle resulted from the damage induced by ROS due to environmental stresses (Ozkur et al. 2009). In this regard, Mirzaee et al. (2013) reported that there is modification in matrix of lipid of the membrane of the plasma induced by salinity, they also added that salinity induce changes in the physical organization of the membrane. Moreover, saline stress resulted in obvious increase in the levels of MDA and $\mathrm{H}_{2} \mathrm{O}_{2}$ in different plant species. Such reduction in MDA contents could be resulted from the effect of $\mathrm{Fe}_{3} \mathrm{O}_{5}$ in reducing the harmful effect of salinity on the built of membranes cell and decreasing the formation of greatly free radicals. $\mathrm{H}_{2} \mathrm{O}_{2}$ is considered a signal molecule in plants subjected to different abiotic stresses. These decreases in response to different treatments were reported earlier by Salama et al. (2009) they reported that the contents of $\mathrm{H}_{2} \mathrm{O}_{2}$ increased in iron-deficient flax leaves. Nanoparticles $\mathrm{Fe}_{3} \mathrm{O}_{4}$ could increase the POD activity (Table 5), which can decrease $\mathrm{H}_{2} \mathrm{O}_{2}$ accumulation and maintain cell membrane integrity (Alexandre et al. 2017). This results as described previously by Elstner and Osswald (1994) may be due to the effect of iron on many enzymes to act correctly especially on the active site of catalase and supermutase which induce wiping of reactive oxygen species.

\section{Effect of foliar application with $\mathrm{Fe}_{3} \mathrm{O}_{4} \mathrm{NPs}$ on Antioxidant} enzymes (POX, PPO, SOD and NR) of Moringa oleifera $\mathrm{L}$.

Data presented in Table 5 show that, foliar treatment of $\mathrm{Fe}_{3} \mathrm{O}_{4}$ NPs caused significant increases in antioxidant enzymes Peroxidase (POX), poly phenol oxidase (PPO), super oxide dismutase (SOD) and nitrate reductase (NR)) of Moringa oleifera L. leaves as compared with untreated plants (control).Maximum increases were obtained by treatment of Moringa oleifera L. plants with $40 \mathrm{ppm}$ $\mathrm{Fe}_{3} \mathrm{O}_{4} \mathrm{NPs}$ nanoparticles (Table 5). Iron is a cofactor for a large numbers of enzymes that catalyze several biochemical processes within the plant. Recently, Rui et al. (2016) and Alexandre et al. (2017) confirmed the induced effect of $\mathrm{Fe}_{3} \mathrm{O}_{4}$ nanoparticles on antioxidant enzymes activities of peanut and wheat plants under stress conditions. Under salinity stress, antioxidant enzymes as well as antioxidant compounds has the ability to protect the plant from harmful effects of stress. Thus, these antioxidant compounds is the very important to safe the plant cell from the harmful effect of Salama et al. (2009). Soliman et al. (2015) reported that, the enhancing effect of the activities of these enzymes could be attributed to the improving role of $\mathrm{Fe}_{3} \mathrm{O}_{4}$ NPs as an important element for plant which acts as a metal constituents of different enzymes as well as, a functional structure or cofactor for protein biosynthesis (Marschner 1995).

\section{Effect of foliar application with $\mathrm{Fe}_{3} \mathrm{O}_{4} \mathrm{NPs}$ on nutritional values of Moringa oleifera $\mathrm{L}$.}

Data in Figure 4 shows the effect of different concentrations of foliar application of treatments on nutritional values of Moringa oleifera L. Foliar application with $\mathrm{Fe}_{3} \mathrm{O}_{4} \mathrm{NPs}$ different concentrations (0, 20, 40 and $\left.60 \mathrm{ppm}\right)$ caused significant increases in nutritional values in comparison to control plants. The same findings reported by Soliman et al. (2015) who found that spraying plants of Moringa with Hoagland containing $\mathrm{ZnO}$ and $\mathrm{Fe}_{3} \mathrm{O}_{4} \mathrm{NP}$ significant increase crude protein level. These increases of nutritional values of moringa leaves could be attributed to the effect of $\mathrm{Fe}_{3} \mathrm{O}_{4} \mathrm{NPs}$ on growth, development as it play important roles in enzyme reactions, photosynthesis, improves the performance of photosystems, DNA transcription, RNA synthesis and auxin activity (Sheykhbaglou et al. 2010).

\section{Effect of foliar application with $\mathrm{Fe}_{3} \mathrm{O}_{4} \mathrm{NPs}$ on nutrients content of Moringa oleifera L.}

Data in Fig. 5 showed that, foliar application with $\mathrm{Fe}_{3} \mathrm{O}_{4}$ NPs different concentrations, significantly and gradually increased contents of $\mathrm{N}, \mathrm{P}, \mathrm{K}, \mathrm{Na}$ and $\mathrm{K} / \mathrm{Na}$ values as compared with control treatment. However, plants sprayed with 40 ppm $\mathrm{Fe}_{3} \mathrm{O}_{4}$ recorded the highest values of $\mathrm{N}, \mathrm{P}$ and $\mathrm{K}$ as well as $\mathrm{K} / \mathrm{Na}$. On the contrary, the lowest $\mathrm{Na}$ content was recorded under same treatment. The increase of $\mathrm{N}, \mathrm{P}$ and $\mathrm{K}$ in this experiment could be due to the promotional effect of $\mathrm{Fe}_{3} \mathrm{O}_{4}$ NPs on growth, physiological and biochemical processes of Moringa oleifera L. 
Magnetite Nanoparticles $\left(\mathrm{Fe}_{3} \mathrm{O}_{4}\right)$ proved to have unique physicochemical properties and super paramagnetism that boosted over all plant metabolisms that affected by biomass and biochemical properties (Abou El-Nasr et al. 2015). In this concern, Soliman et al. (2015) concluded that spraying plants of Moringa with Hoadland containing $\mathrm{ZnO}$ and $\mathrm{Fe}_{3} \mathrm{O}_{4}$ NP resulted in obvious decrease in $\mathrm{Na} \mathrm{Cl}$ and increase in N, P and $\mathrm{K}$. Moreover, these results related with the findings of Ahmed et al. (2016) they reported that $\mathrm{N}, \mathrm{P}$ and $\mathrm{K}$ was gradually decreased with increasing salinity level, but was progressively increased as the rate of $\mathrm{Fe}_{3} \mathrm{O}_{4}$ was increased, they added $\mathrm{Na}$ content was in descending order, but that of $\mathrm{Cl}$ and proline was gradually increased with increasing $\mathrm{Fe}_{3} \mathrm{O}_{4}$ dose.

\section{Conclusion}

The results showed that, foliar application with $40 \mathrm{ppm}$ $\mathrm{Fe}_{3} \mathrm{O}_{4}$ nanoparticles enhanced all studied growth characters as well as photosynthetic pigments content and crude protein as well as the physiological aspects of the Moringa. We can recommend that $\mathrm{Fe}_{3} \mathrm{O}_{4}$ nanoparticles can play important role to promote the growth of plants especially in salt affected environment by regulating physiological and biochemical processes in response to salt induced stress. High and low, concentration of $\mathrm{Fe}_{3} \mathrm{O}_{4}$ nanoparticles was less effective.

\begin{abstract}
Abbreviations
$\mathrm{Fe}_{3} \mathrm{O}_{4} \mathrm{NPS}$ : Iron oxide nanoparticles; chlo.a: Chlorophyll a; chlo b: Chlorophyll b; chlo a/b: Chlorophyll a/Chlorophyll b; IAA: Indole acetic acid; POX: Peroxidase; PPO: Polyphenol oxidase; SOD: Super oxide dismutase; NR: Nitrate reductase; N: Nitrogen; P: Phosphorus; K: Potassium; K/Na: Potassium sodium ratio; ROS: Reactive oxygen species; DNA: Deoxy ribonucleic acid; RNA: Ribo nucleic acid; MNPs: Magnetite nanoparticles; TSS: Total soluble sugars.
\end{abstract}

\section{Acknowledgements}

The Authors express their appreciations to the National Research Centre who financed the project of "Application of biosaline agriculture concept for sustainable uses in saline environments" (Project No. 10060105).

\section{Authors' contributions}

MMT, MHM and ATT designed and farming plants, statistical analysis and wrote and reviewed the manuscript. MShS, designed and performed the experiment, responsible of all the physiological and biochemical analysis and also wrote and reviewed the manuscript. All authors read and approved the final manuscript.

\section{Funding}

There are currently no funding sources in the design of the study and collection, analysis and interpretation of data, and in writing of the manuscript.

\section{Availability of data and materials}

The datasets generated and/or analyzed during the current study are included in this published manuscript.

\section{Declarations}

Ethics approval and consent to participate Not applicable.
Consent for publication

Not applicable.

\section{Competing interests}

The authors declare that they have no competing interests.

\section{Author details}

${ }^{1}$ Field Crops Research Department, Institute of Agricultural and Biological Research, National Research Centre, P.O. 12622, Giza, Egypt. ²Botany Department, Institute of Agricultural and Biological Research, National Research Centre, P.O. 12622, Giza, Egypt. ${ }^{3} 33$ El Bohouth st, P.O. 12622, Giza, Egypt.

Received: 1 June 2021 Accepted: 24 September 2021

Published online: 27 October 2021

\section{References}

Abdel-Fattah GH (2014) The role of magnetic iron and sodium selenate in minimizing soil salt hazards on growth and quality of Jacaranda acutifolia Humb. \& Bonpl. seedlings. Sci J Flowers Ornam Plants 1(3):187-198

Abou El-Nasr MK, El-Hennawy HM, El-Kereamy AMH, Abou El-Yazied A, Salah Eldin TA (2015) Effect of magnetite nanoparticles $\left(\mathrm{Fe}_{3} \mathrm{O}_{4}\right)$ as nutritive supplement on pear saplings. Middle East J Appl Sci 5(3):777-785

Ahmed MA, Abdel-Fattah GH, Shahin SM (2016) The role of magnetic iron in enhancing the ability of Acalypha wilkesiana MÜLL. ARG transplants to tolerate soil salinity. J Plant Prod 7(3):379-384

Alexandre K, Xiao H, Zhiyong Z, Yuhui M, Peng Z, Gibson MA, Yukui R (2017) Magnetic $\left(\mathrm{Fe}_{3} \mathrm{O}_{4}\right)$ nanoparticles reduce heavy metals uptake and mitigate their toxicity in wheat seedling. Sustainability 9:790. https://doi.org/10. 3390/su9050790

Alharby HF, Metwali EMR, Fuller MP, Aldhebiani AY (2016) Impact of application of zinc oxide nanoparticles on callus induction, plant regeneration, element content and antioxidant enzyme activity in tomato (Solanum lycopersicum Mill.) under salt stress. Arch Biol Sci 68(4):723-735

Al-Rawahy SA, Al-Dhuhli HS, Prathapar S, AbdelRahman H (2011) Mulching material impact on yield, soil moisture and salinity in saline-irrigated sorghum plots. Int J Agric Res 6(1):75-81

Anwar F, Latif S, Ashraf M, Gilani AH (2007) Moringa oleifera: a food plant with multiple medicinal uses. Phytother Res 21:17-25

AOAC (2010) Official Methods of Analysis. 18th Edition, Revision 3, Association of Official Analytical Chemists, Washington, DC

Askary M, Talebi SM, Amini F, Bangan DBA (2016) Effect of $\mathrm{NaCl}$ and iron oxide nanoparticles on Mentha piperita essential oil composition. Environ Exp Bot 14:27-32

Askary M, Talebi SM, Amini F, Bangan AD (2017) Effects of iron nanoparticles on Mentha piperita L. under salinity stress. Biologija 63(1):65-75

Auffan M, Rose J, Bottero JY, Lowry GV, Jolivet JP, Wiesner MR (2009) Towards a definition of inorganic nanoparticles from an environmental, health and safety perspective. Nat Nanotechnol 4:634

Baruah S, Dutta J (2009) Nanotechnology applications in pollution sensing and degradation in agriculture: a review. Environ Chem Lett 7(3):191-204

Bastani S, Hajiboland R, Khatamian M, SaketOskoui M (2018) Nano iron (Fe) complex is an effective source of Fe for tobacco plants grown under low Fe supply. J Soil Sci Plant Nutr 8(2):524-541

Bates LS, Waldan RP, Teare LD (1973) Rapid determination of free proline under water stress studies. Plant Soil 39:205-207

Bergmeyer HU (1974) Methods of Enzymatic Analysis"I, 2nd edn. Academic Press, New York

Briat JF, Dubos C, Gaymard F (2015) Iron nutrition, biomass production, and plant product quality. Trends Plant Sci 20:33-40

Broadley M, Brown P, Kakmak I, Rengel Z, Zhao F (2012) Function of nutrients: micronutrients. In: Marschner P (ed) Marschner's mineral nutrition of higher plants. Academic Press, London, pp 71-84

Ciha AJ, Brun WA (1978) Effect of pod removal on nonstructural carbohydrate concentration in soybean tissue. Crop Sci 18:773-776

Cossins, D. (2014). Next generation: nanoparticles augment plant functions. The incorporation of synthetic nanoparticles into plants can enhance photosynthesis and transform leaves into biochemical sensors. The scientist, news \& opinion, March16. http://www.Thescientist.com/?artic 
les.view/articleNo/39440/title/Next-Generation-Nanoparticles-Augme nt-Plant-Functions/

Dhindsa R, Plumb-Dhindsa P, Thorpe T (1981) Leaf senescence correlated permeability, lipid peroxidation and decreased levels of superoxide dismutase and catalase. J Exp Bot 32:93-101

Dimetry ZD, Hany MH (2016) Role of nanotechnology in agriculture with special reference to pest control. Int J Pharm Tech Res 9(10):121-144

Dolatabadian A, Saleh RJ (2009) Impact of exogenous ascorbic acid on antioxidant activity and some physiological traits of common bean subjected to salinity stress. Not Bot Hort Agrobot Cluj 37(2):165-172

El-Sayed HEA (2014) Impact of magnetic water irrigation for improve the growth, chemical composition and yield production of broad bean (Vicia faba L.) plant. Am J Exp Agric 4(4):476-496

Elstner F, Osswald W (1994) Mechanism of oxygen activation during plant stress. Proc R Sci Edinb 102:131-154

Eman NA (2014) Moringa oleifera Leaves Possible uses as environmentally Friendly Material: A REVIEW International Journal of Chemical. Environ Biol Sci (IJCEBS) 2(2):2320-4087

Eppendrof N, Hing G (1970) Interaction manual of flame photometer B 700-E. Measuring method, Description of the apparatus and Instructions for use

Ezzo M, Abd-Elhamid EM, Sadak MS, Abdalla AM (2018) Improving drought tolerance of moringa plants by using trehalose foliar treatments. Biosci R 5(4):4203-4214

Farhangi-Abriz S, Ghassemi-Golezani K (2018) How can salicylic acid and jasmonic acid mitigate salt toxicity in soybean plants? Ecotox Environ Saf 147:1010-1016

Gusmiaty M, Restu A, Payangan RY (2019) Production of IAA (Indole Acetic Acid) of the rhizosphere fungus in the Suren community forest stand IOP conference series: earth and environmental science 343, 012058 IOP Publishing. https://doi.org/10.1088/1755-1315/343/1/012058

Hasan SA, Hayat SH, Ahmad A (2011) Brassino steroids protect photosynthetic machinery against the cadmium induced oxidative stress in two tomato cultivars. Chemosphere 84:1446-1451

Heath RL, Packer L (1968) Photoperoxidation in isolated chloroplasts. I. Kinetics and stoichiometry of fatty acid peroxidation. Archives in Biochem and Biophysics 125:189-198

Jana S, Choudhuri M (1981) Glycolate metabolism of three submerged aquatic angiosperms during aging. J Aquat Bot 12:345-354

Jaworski EG (1971) Nitrate reductase assay in intact plant tissues. Biochem Biophys Res Commun 43:1274-1279

Kar M, Mishra D (1976) Catalase, peroxidase and polyphenol oxidase activities during rice leaf senescence. Plant Physiol 57:315-319

Karimi HR, Ebadi A, Zamani Z, Fatahi R (2011) Effects of water salinity on growth indices and physiological parameters in some pistachio rootstocks. J Plant Nutr 34:935-944

Kaur G, Asthir B (2015) Proline: a key player in plant abiotic stress tolerance. Biol Plant 59(4):609-619

Klute A (1986) Methods of soil analysis. 2nd ed. Part 1: physical and mineralogical methods. Part 2: chemical and microbiological properties. Madifon, Wesconsin, USA

Lichtenthaler HK, Buschmann C (2001) Chlorophylls and carotenoids: measurement and characterization by UV-VIS spectroscopy. In: Wrolstad RE, Acree TE, An H, Decker EA

Mai HJ, Bauer P (2016) From the proteomic point of view: integration of adaptive changes to iron deficiency in plants. Current Plant Biol 5:45-56

Marschner H (1995) Mineral nutrition of higher plants. Academic Press, London

Mekonnen D (2016) Miracle tree: a review on multi-purposes of Moringa oleifera and its implication for climate change mitigation. J Earth Sci Clim Change7:366. https://doi.org/10.4172/2157-7617.1000366.

Mengel K (1991) Ernahrung und Stoffwechsel der Pflanze. Spektrum Akademischer Verlag Press, New York

Mirzaee M, Moieni A, Ghanati F (2013) Effects of drought stress on the lipid peroxidation and antioxidant enzyme activities in two canola (Brassica napus L.) cultivars. J Agron Sci Tech 15:593-602

MSTAT-C (1988) MSTAT-C, a microcomputer program for the design, arrangement and analysis of agronomic research. Michigan State University, East Lansing. Mukherjee, S. P. and M. A.

Mukherjee SP, Choudhuri MA (1983) Implication of water stress-induced changes in the levels of endogenous ascorbic acid and hydrogen peroxide in vigna seedling. Physiol Plant 58:166-170
Munns R, James R, Lauchli A (2006) Approaches to increasing the salt tolerance of wheat and other cereals. J Exp Bot 53:39-47

Nanjo T, Kobayashi M, Yoshiba Y, Sanada Y, Wada K, Tsukaya H, Kakubari Y, Yamaguchi-Shinozaki K, Shinozaki K (1999) Biological functions of proline in morphogenesis and osmotolerance revealed in antisense transgenic Arabidopsis thaliana. Plant J 18:185-193

Omisun T, Sahoo S, Saha B, Panda SK (2018) Relative salinity tolerance of rice cultivars native to North East India: a physiological, biochemical and molecular perspective. Protoplasma 255:193-202

Ozkur O, Ozdemir F, Bor M, Turkan I (2009) Physiochemical and antioxidant responses of the perennial xerophyte Capparis ovata Desf. to drought. Environ Exp Bot 66:487-492

Rastogi A, Zivcak M, Sytar O, Kalaji HM, He X, Mbarki S, Brestic M (2017) Impact of metal and metal oxide nanoparticles on plant: a critical review. Front Chem 5:78

Rui M, Ma C, Hao Y, Guo J, Rui Y, Tang X, Zhao Q, Fan X, Zhang Z, Hou T, Zhu S (2016) Iron oxide nanoparticles as a potential iron fertilizer for peanut (Arachis hypogaea). Front Plant Sci. https://doi.org/10.3389/fpls.2016.00815

Salama ZAE, El-Beltagi HS, El-Hariri DM (2009) Effect of Fe deficiency on antioxidant system in leaves of three flax cultivars. Not Bot Hort Agrobot Cluj 37(1):122-128

Sanati S, Razavi BM, Hosseinzadeh H (2018) A review of the effects of Capsicum annuum $L$. and its constituent, capsaicin, in metabolic syndrome. Iran J Basic Med Sci 21(5):439-448

Shahrekizada M, Gholamalizadeh A, Ahangara NM (2015) EDTA-Coated $\mathrm{Fe}_{3} \mathrm{O}_{4}$ nanoparticles: a novel biocompatible fertilizer for improving agronomic traits of sunflower (Helianthus Annuus). J Nanostruct JNS 5:117-127

Shankramma K, Yallappa S, Shivanna MB, Manjanna J (2016) $\mathrm{Fe}_{2} \mathrm{O}_{3}$ magnetic nanoparticles to enhance $S$. lycopersicum (tomato) plant growth and their biomineralization. Appl Nanosci 6:983-990. https://doi.org/10. 1007/s13204-015-0510-y

Sheykhbaglou R, Sedghi M, Tajbakhsh Shishevan M, Seyed Sharifi R (2010) Effects of nano-iron oxide particles on agronomic traits of soybean. Nor Sci Bioil 2:112-113

Sheykhbaglou R, Sedghi M, Fathi-Achachlouie B (2018) The Effect of Ferrous Nano-oxide Particles on Physiological Traits and Nutritional Compounds of Soybean (Glycine max L.) Seed. Anais da Academia Brasileira de Ciências 90(1): 485-494 (Annals of the Brazilian Academy of Sciences) Printed version ISSN 0001-3765/ Online version ISSN 1678-2690. https://doi.org/10.1590/0001-3765201820160251 www.scielo.br/aabc | www.fb.com/aabcjournal

Siddiqui MH, Al-Whaibi MH, Firoz M, Al-Khaishany MY (2015) Role of nanoparticles in plants. http://www.springer.com/978-3-319-14501-3. 21.

Silva C, Martinez V, Carvajal M (2008) Osmotic versus toxic effects of $\mathrm{NaCl}$ on pepper plants. Biol Plant 52(1):72-79

Soliman AS, El-feky SA, Darwish E (2015) Alleviation of salt Strees on Moringa peregrine using foliar application of nanofertilizers. J Hortic For 7(2):36-47

Tester M, Davenport R (2003) Na+ tolerance and $\mathrm{Na}+$ transport in higher plants. Ann Bot 91:503-527

Tripathi DK, Singh S, Singh VP, Prasad SM, Dubey NK, Chauhan DK (2017) Silicon nanoparticles more effectively alleviated UV-B stress than silicon in wheat (Triticum aestivum) seedlings. Plant Physiol Biochem 110:70-81

Vartainan N, Hervochon P, Marcolte L, Larher F (1992) Proline accumulation during drought rhizogenesis in Brassica napus var. Oleifera Plant Physiol 140:623-628

Yemm EW, Cocking EC (1955) The determination of amino acids with ninhydrin. Analyst 80:209-213

Yew YP, Shameli K, Miyake M, Kuwano N, Khairudin NBA, Mohamed SE, Lee KX (2016) Green synthesis of magnetite $\left(\mathrm{Fe}_{3} \mathrm{O}_{4}\right)$ nanoparticles using seaweed (Kappaphycus alvarezii) extract Nanoscale Res. Lett 11:276

Zhang XZ (1993) Crop physiology research method. China Agricultural Press, Beijing, pp 145-146

Zheng Y, Xu B, Ren K, Zhang Y, Wu J (2017) Impact of soil drench and foliar spray of 24-epibrassinolide on the growth, yield, and quality of field-grown Moringa oleifera in Southwest China. J Plant Growth Regul 36:931-941

\section{Publisher's Note}

Springer Nature remains neutral with regard to jurisdictional claims in published maps and institutional affiliations. 